\title{
Możliwość prowadzenia przez partie polityczne kampanii społecznych ${ }^{1}$
}

Admissibility of running social campaigns by political parties: Political parties may legitimately undertake public activities (including the so-called social campaigns) aimed at encouraging citizens to provide financial support, in the form of pecuniary donations, to monetary works aimed at the implementation of a specific activity of a party within the framework of "influencing with democratic methods the state policy" and statutory goals of a given party. Such activities cannot take the form of a public collection, i.e. involve the collection of funds in cash or in kind in public places or encourage such activities. Payments to political parties made in connection with a specific purpose (e.g. preparation of a bill) are subject to the subjective and quota restrictions set out in the Act on Political Parties.

Keywords: political party | donation | public collection

Słowa kluczowe: partia polityczna | darowizna | zbiórka publiczna

Doktor nauk prawnych, starszy wykładowca na Uniwersytecie Jagiellońskim, ekspert ds. legislacji BAS; piotr.czarny@neostrada.pl.

\section{Zagadnienia wstępne}

Przedmiotem niniejszej opinii prawnej jest odpowiedź pytanie: czy partie polityczne w Polsce - w świetle obowiązujących przepisów prawa - mogą legalnie prowadzić kampanie społeczne (poprzez np. publikacje plakatów/ogłoszeń) zachęcające obywateli do finansowego wsparcia w tworzeniu danego projektu ustawy?

Niniejsza opinia ma charakter ogólny i nie odnosi się wprost do konkretnej sytuacji. Została sporządzona przede wszystkim na podstawie przepisów ustawy z 27 czerwca 1997 r. o partiach politycznych (t.j. Dz.U. 2017, poz. 876) oraz prze-

1 Opinia prawna w sprawie prowadzenia przez partie polityczne kampanii społecznych sporządzona 13 listopada 2017 r. na zlecenie Klubu Parlamentarnego Prawo i Sprawiedliwość; BAS-WAKiU 2137/17. 
pisów tytułu XXXIII księgi trzeciej Kodeksu cywilnego (t.j. Dz.U. 2017, poz. 459; dalej: k.c.).

Ze względu na odrębnie określone cele i zasady działania europejskich partii politycznych tezy i ustalenia niniejszej opinii nie odnoszą się do tego rodzaju organizacji.

\section{Uzasadnienie i ustalenia szczegółowe}

1. Należy na początku ustalić, co oznacza pojęcie „kampania społeczna”. Nie jest to termin prawnie zdefiniowany. Ogólnie przyjmuje się, że: [k]ampania społeczna jest forma działań społecznie zaangażowanych organizacji, obok akcji czy programu społecznego. Jest to medialna kampania realizowana najczęściej przy współpracy różnych podmiotów, majaca na celu rozwiązanie jakiegoś problemu społecznego, promocję wartości lub zmianę postaw; umożliwia różne typy wsparcia - finansowe, rzeczowe, usługowe. W innym ujęciu określenie to rozumiane jest: jako zestaw różnych działań zaplanowanych w konkretnym czasie, skierowanych do określonej grupy docelowej, której celem jest doprowadzenie do wzrostu wiedzy, zmiany myślenia, zachowania wobec określonego problemu społecznego lub prowadzi do rozwiązywania problemu społecznego blokującego osiaganie dobra wspólnego zdefiniowanego jako dany cel marketingowy. Kampania społeczna może stosować narzędzia i techniki reklamowe oraz $P R^{2}$.

Niezależnie od tego, jak dokładnie definiować kampanie społeczne, stwierdzić należy ogólnie, że dopuszczalność ich prowadzenia przez partie polityczne wynika z art. 11 Konstytucji RP, który poręcza m.in. wolność działania partii politycznych. Organizacja tego typu może w swojej działalności wykorzystywać różnorodne środki i sposoby, o ile mieszczą się one w szeroko pojętych ramach działania w celu: wpływania metodami demokratycznymi na kształtowanie polityki państwa. Jak się wskazuje w literaturze: [u]strojodawca wskazał w ten sposób na wielość i różnorodność działań, za pomoca których partia może wpływać na kształt polityki państwa. Tak zakreślony cel nie ogranicza działalności partyjnej do udziału w wyborach czy dązenia do zdobycia władzy. Wpływ na kształt polityki państwa partie wywierać powinny przez angażowanie opinii publicznej do debaty nad polityka państwa, profesjonalizacje polityki (np. przez wykorzystywanie funduszów eksperckich), rozmaite procedury kontrolne (np. interpelacyjne), ocene prowadzonej polityki czy proponowanie własnych rozwiązańn ${ }^{3}$. Niewątpliwie ini-

2 B. Tarczydło, Kampania społeczna $w$ teorii i praktyce, https://www.ue.katowice.pl/ fileadmin/_migrated/content_uploads/19_B.Tarczydlo_Kampania_spoleczna_w_ teorii_i_praktyce.pdf [dostęp 6 listopada 2017 r.].

3 J. Sułkowski, Uwaga 39 do art. 11 [w:] Konstytucja RP, t. I, Komentarz do art. 1-86, red. M. Safjan, L. Bosek, Warszawa 2016, s. 361. 
cjowanie i prowadzenie kampanii społecznej w sprawie przygotowania projektu ustawy mieści się w pojęciu angażowania opinii publicznej, jak również związane jest z proponowaniem własnych rozwiązań.

Należy oczywiście zgłosić zastrzeżenie, że działania partii politycznych również w zakresie kampanii społecznych nie mogą naruszać art. 13 Konstytucji. Temat prowadzonej kampanii nie może zatem: odwoływać się do totalitarnych metod i praktyk działania nazizmu, faszyzmu i komunizmu, oraz zakładać albo dopuszczać nienawiści rasowej i narodowościowej. Wykluczone jest także stosowanie przemocy. Niezależnie od tego, za naruszenie prawa należałoby również uznać takie określenie celu i założeń kampanii społecznej, które stanowiłoby przestępstwo, np. publiczne nawoływanie do wszczęcia wojny napastniczej lub pochwałę takiej wojny (art. $117 \S 3$ Kodeksu karnego) czy też publiczne nawoływanie do popełnienia przestępstwa albo publiczną pochwałę przestępstwa (art. 255 Kodeksu karnego).

Z zasady wolności działania partii politycznych wynika, że wszelkie ograniczenia w tej dziedzinie wynikać powinny wyraźnie z przepisów Konstytucji RP lub ustaw. Co do „publikacji” plakatów zwrócić trzeba uwagę, że zgodnie z art. 63 $\$ 1$ Kodeksu wykroczeń legalne umieszczanie w miejscu publicznym do tego nieprzeznaczonym ogłoszeń, plakatów, afiszów, apeli, ulotek, napisów lub rysunków albo ich wystawianie na widok publiczny w innym miejscu wymaga zgody zarządzającego tym miejscem.

2. Jeśli chodzi o majątkowy aspekt prowadzenia przez partię polityczną kampanii społecznej, tj. o różne metody zachęcania do wsparcia finansowego określonych zamierzeń (celów), to na początku stwierdzić należy, że zgodnie z art. 24 ust. 1 ustawy o partiach politycznych majątek tego typu organizacji: powstaje ze składek członkowskich, darowizn, spadków, zapisów, $z$ dochodów z majątku oraz $z$ określonych ustawami dotacji i subwencji. Do darowizn, spadków i zapisów wobec braku ich bliższego zdefiniowania w ustawie o partiach politycznych - zastosowanie znajdują przepisy Kodeksu cywilnego ${ }^{4}$. Darowizną w świetle art. 888 $\$ 1$ k.c. jest nieodpłatne świadczenie na rzecz obdarowanego kosztem majątku darczyńcy. Finansowe wsparcie partii politycznej w sytuacji, gdy osoba go dokonująca nie ma otrzymać od partii żadnego świadczenia o charakterze majątkowym, które byłoby „ekonomicznym ekwiwalentem” dokonanego „wsparcia”, kwalifikować należy pod względem prawnym jako darowiznę. Oczywiste jest, że cel wsparcia finansowego w postaci przygotowania („stworzenia”) projektu nie jest tego rodzaju działaniem, które zmieniałoby ocenę prawną wpłat na rzecz partii politycznych. Ponieważ darowizny na rzecz partii politycznych są - choć pod pewnymi warunkami - dopuszczalne, to nie można uznać, że zwracanie się o nie również do nieokreślonego imiennie kręgu osób, a więc w formie tzw.

4 M. Dębska, Ustawa o partiach politycznych. Komentarz, 2013, LexisNexis, uwaga 4 do art. 24. 
kampanii społecznej - jest czymś zabronionym. W rozumieniu prawa cywilnego zachęcanie do wpłat na rzecz partii politycznych poprzez ogłoszenia i inne informacje stanowi prawnie dopuszczalne zaproszenie do zawarcia umowy, a konkretnie umowy darowizny (art. 71 k.c.).

Partie mogą zwracać się o darowizny na ich rzecz zarówno w zakresie swojej „ogólnej” działalności statutowej, jak i „pomoc” tego rodzaju w realizacji konkretnych zamierzeń. Kwestia, na jaki konkretnie cel darczyńca dokonuje świadczenia na rzecz obdarowanego, nie należy bowiem do konstytutywnych elementów umowy darowizny. Jak stwierdził Sąd Najwyższy w wyroku z 6 października 2017 r. sygn. akt II CK 39/045: [o] drębną kwestia sa natomiast-niestanowiace już warunku prawnego bytu umowy [darowizny - dopisek P.C.] - osobiste motywy dokonania darowizny, która może służyć rozmaitym celom indywidualnym i społecznym. Pobudka doprowadzająca do zawarcia umowy może być chęć wyrażenia uczucia przywiąania lub wdzięczności, wyświadczenia przysługi lub niesienia pomocy, uzyskania przyjaźni lub odpowiedniego postępowania osoby obdarowanej bądź przysłużenia się oznaczonym celom podjętym $w$ interesie ogółu. Partie polityczne mogą wskazywać potencjalnym darczyńcom również określone zamierzenia o charakterze publicznym, które mają skłonić tych ostatnich do dokonania darowizny, a więc odwoływać się do potencjalnych pobudek ewentualnych darczyńców.

Poza tym z art. 893 k.c. wynika, że darczyńca może włożyć na obdarowanego obowiązek oznaczonego działania lub zaniechania, nie czyniąc nikogo wierzycielem (polecenie). Nie wnikając w szczegóły, stwierdzić należy, że darczyńca może również wskazać partii politycznej (jako obdarowanemu) określone zamierzenie, które powinna ona podjąć lub dążyć do jego realizacji. Trzeba przyjąć, że także ten element może być ujęty w „zaproszeniu do zawarcia umowy” (umowy darowizny), jakim - co już wspomniano - mogą być ogłoszenia (plakaty) i inne informacje upowszechniane przez partie polityczne.

3. Ustawa o partiach politycznych wprowadza zakaz przeprowadzania przez partie polityczne zbiórek publicznych (art. 24 ust. 6). Zgodnie z art. 1 ust. 1 ustawy z 14 marca 2014 r. o zasadach prowadzenia zbiórek publicznych (t.j. Dz.U. 2017, poz. 1223) zbiórką publiczną jest: zbieranie ofiar w gotówce lub $w$ naturze $w$ miejscu publicznym na określony, zgodny z prawem cel pozostający $w$ sferze zadań publicznych, o których mowa $w$ art. 4 ust. 1 ustawy z 24 kwietnia 2003 r. o działalności pożytku publicznego i o wolontariacie (Dz. U. z 2016 r. poz. 1817 i 1948 oraz z 2017 r. poz. 60 i 573), oraz na cele religijne. Oznacza to m.in., że formy zachęcania do wpłat na rzecz partii politycznych nie mogą mieć cech konstytutywnych zbiórki publicznej, tj. polegać na uzyskiwaniu środków finansowych w gotówce lub naturze w miejscach publicznych. Odnosząc się do postawionego we wstępie pytania, stwierdzić należałoby, że ewentualna kampania społeczna,

$5 \quad$ LEX nr 1448701. 
mająca na celu uzyskanie przez partię polityczną finansowego wsparcia obywateli nie powinna przewidywać działań charakterystycznych dla zbiórki publicznej, tj. odbywać się poprzez wskazywanie miejsc publicznych, w których możliwe jest dokonywanie wpłat na określony cel w gotówce lub też w formie rzeczowej.

4. Ustawa o partiach politycznych zawiera ponadto ograniczenia podmiotowe oraz (względne i bezwzględnie) ograniczenia kwotowe dotyczące wpłat na rzecz partii politycznych. Zgodnie z art. 25 ust. 1: [p]artii politycznej moga być przekazywane środki finansowe jedynie przez obywateli polskich majacych stałe miejsce zamieszkania na terenie Rzeczypospolitej Polskiej, z zastrzeżeniem przepisów art. 24 ust. 4 i 7, art. 28 ust. 1 oraz przepisów ustaw dotyczących wyborów do Sejmu Rzeczypospolitej Polskiej i do Senatu Rzeczypospolitej Polskiej oraz wyborów do Parlamentu Europejskiego w zakresie dotacji podmiotowej. W myśl art. 25 ust. 4: łączna suma wpłat od osoby fizycznej na rzecz partii politycznej, z wyłaczeniem składek członkowskich $w$ kwocie nieprzekraczającej $w$ jednym roku minimalnego wynagrodzenia za pracę, ustalanego na podstawie odrębnych przepisów, obowiązującego w dniu poprzedzającym wpłatę, oraz wpłat na Fundusz Wyborczy partii politycznej, nie może przekraczać w jednym roku 15-krotności minimalnego wynagrodzenia za prace, ustalanego na podstawie odrębnych przepisów, obowiazującego $w$ dniu poprzedzającym wpłatę. Poza tym art. 25 ust. 5 przewiduje, że: jednorazowa wpłata kwoty przekraczajacej minimalne wynagrodzenie za prace, ustalane na podstawie odrębnych przepisów, obowiąujące $w$ dniu poprzedzajacym wpłatę, może być dokonywana na rzecz partii politycznej jedynie czekiem rozrachunkowym, przelewem lub kartą płatniczą. Przyjąć należy, że ograniczenia powyższe dotyczą również darowizn na rzecz partii politycznych ${ }^{6}$. Powoduje to, że partia polityczna w ramach tzw. kampanii społecznej nie powinna upowszechniać informacji, które mogłyby wprowadzać potencjalnych darczyńców w błąd jeśli chodzi o dopuszczalność darowizny, np. przez prowadzenie kampanii wśród obywateli polskich zamieszkałych za granicą, sugerowanie wpłat przekraczających ustawowe limity. Stanowić by to mogło naruszenie art. $286 \$ 1$ Kodeksu karnego (wprowadzenie w błąd w celu osiągnięcia korzyści majątkowej).

\section{Podsumowanie}

- Partie polityczne mogą zgodnie z prawem podejmować publicznie działania (również tzw. kampanie społeczne) zmierzające do zachęcenia obywateli do finansowego wsparcia w formie darowizn pieniężnych prac mających na celu realizację konkretnego zamierzenia partii mieszczącego się $\mathrm{w}$ ramach $w p \not y$ wania metodami demokratycznymi na kształtowanie polityki państwa i statutowych celów danej partii (np. przygotowania określonego projektu ustawy).

6 M. Dębska, Ustawa o partiach, op. cit. 
W sensie cywilnoprawnym działania takie stanowią dopuszczalne zaproszenie do zawarcia umowy (umowy darowizny).

- Opisane wyżej działania nie mogą mieć charakteru zbiórki publicznej, tj. polegać na zbieraniu środków finansowych w gotówce lub w naturze w miejscach publicznych ani też zachęcać do takich działań.

- Wpłaty na rzecz partii politycznych dokonywane w związku z określonym zamierzeniem (np. przygotowaniem projektu ustawy) podlegają ograniczeniom podmiotowym i kwotowym określonym w ustawie o partiach politycznych. W działaniach zachęcających do wpłat partie powinny unikać przekazywania takich informacji, które wprowadzałyby potencjalnych darczyńców w błąd co do dopuszczalności przekazywania darowizn.

\section{Bibliografia}

Dębska M., Ustawa o partiach politycznych. Komentarz, 2013, LexisNexis.

Sułkowski J., Uwaga 39 do art. 11 [w:] Konstytucja RP. Kometarz, t. I, Art. 1-86, red. M. Safjan, L. Bosek, Warszawa 2016.

Tarczydło B., Kampania społeczna $w$ teorii i praktyce, https://www.ue.katowice.pl/fileadmin/_migrated/content_uploads/19_B.Tarczydlo_Kampania_spoleczna_w_teorii_i_ praktyce.pdf. 